Original Article

\title{
SPECTROPHOTOMETRIC METHOD FOR THE DETERMINATION OF AMIKACIN IN PURE AND PHARMACEUTICAL DOSAGE FORM
}

\author{
SURYA TEJA G., GURUPADAYYA B. M. ${ }^{*}$, VENKATA SAIRAM K. \\ Department of Pharmaceutical Chemistry, JSS College of Pharmacy, Jagadguru Sri Shivarathreeshwara University, Mysore 570015, \\ Karnataka, India \\ Email: bmgurupadayya@jssuni.edu.in
}

Received: 21 Oct 2017, Revised and Accepted: 12 Dec 2017

\section{ABSTRACT}

Objective: The aim of the study was to develop an easy, sensible and rapid method for the estimation of amikacin in both pure and marketed formulation using the spectrophotometric method.

Methods: Due to lack of chromophoric group in the amikacin, it was derivatized with 0.1 mmol chloranillic acid reagent. For the estimation of amikacin, Shimadzu UV-1700 model spectrophotometer with UV probe software was used. The method was based on simple charge transfer complexation of the drug with a p-chloranillic acid reagent to give a purple coloured product which was measured at $524 \mathrm{~nm}$ against blank solution.

Results: The derivatised product of amikacin was detected at a wavelength of $524 \mathrm{~nm}$. Linearity was observed with the concentration range of 20 $100 \mu \mathrm{g} / \mathrm{ml}$ with a regression coefficient of 0.9803 . Results of all the parameters were within the acceptance criteria with \% RSD less than 2.

Conclusion: The spectroscopic method was validated as per ICH guidelines and was found to be applicable for routine quantitative analysis of amikacin in marketed formulations also. The results of linearity, precision, accuracy LOD and LOQ were within the specified limits. The method is highly sensitive, robust, reproducible and specific.

Keywords: Amikacin, Analytical method development, ICH guidelines, Pharmaceutical dosage, Spectrophotometric.

(C) 2018 The Authors. Published by Innovare Academic Sciences Pvt Ltd. This is an open-access article under the CC BY license (http://creativecommons.org/licenses/by/4.0/) DOI: http://dx.doi.org/10.22159/ijcpr.2018v10i1.24703

\section{INTRODUCTION}

Amikacin is an aminoglycoside antibiotic used for many gram-negative bacterial infections like infections in the urinary tract, infections in brain, lungs and abdomen which are resistant to gentamicin, kanamycin or tobramycin. When compared to other aminoglycosides amikacin has very narrow safety margin i.e., its therapeutic plasma concentration is $8-16 \mu \mathrm{g} / \mathrm{ml}$. When it is given to renal impaired patients for over a period of time it shows ototoxicity and nephrotoxicity [1-3].

A detailed literature review indicated that there are few analytical and bioanalytical methods were reported like calorimetry [4], HPLC [5-8], LCMS [9] and immunoassay [9]. But till date, there were no reported methods for UV visible Spectroscopy by using choloranilic acid as a derivatizing agent. This method is simple, sensitive, rapid and can be possible to extend to HPLC method using similar reagent.<smiles>NCCC(O)C(=O)NC1C[C@@H](N)[C@H](O[C@@H]2OC(CN)[C@@H](O)C(O)[C@H]2O)[C@H](O[C@@H]2OC(O)[C@H](O)[C@H](N)[C@H]2O)C1O</smiles>

Fig. 1: Amikacin chemical structure

The structure of amikacin was shown in fig. 1, which has four primary amine groups, one secondary amine group, one primary $\mathrm{OH}$ group and seven secondary OH groups [10]. Direct UV methods are not available in literature because the drug is not absorbing in the UV region. Hence, it is essential to derivatize with $0.1 \%$ chloranilic acid using electron transfer reaction. The detailed chemical reaction between amikacin and chloranillic acid was shown in fig. 2.

\section{METHODS AND MATERIALS}

\section{Equipment}

Absorbance and spectral were measured by using Shimadzu UVvisible spectrophotometer model 1800 with $1 \mathrm{~cm}$ pair quartz cells. Shimadzu electronic weighing balance was used for weighing samples.

\section{Chemicals and reagents}

Amikacin Sulfate was procured from Shri Chem, Mumbai and Chloranillic acid was procured from Loba chem and acetonitrile from Merck.

\section{Amikacin standard stock solution}

$100 \mathrm{mg}$ pure drug of amikacin was taken into $100 \mathrm{ml}$ volumetric flask and dissolved with distilled water and made up to mark with distilled water. Further $10 \mathrm{ml}$ was taken from the above solution and diluted to $100 \mathrm{ml}$ with distilled water to get $100 \mu \mathrm{g} / \mathrm{ml}$ solution. From these serial dilutions were made to get $20,40,60,80$ and 100 $\mu \mathrm{g} / \mathrm{ml}$ solutions.

$0.1 \%$ mmol chloranilic acid reagent $[11,12]$

Solution A (1\% chloranilic acid): 0.208 gms of cholranilic acid was weighed into $100 \mathrm{ml}$ volumetric flask and dissolved in few $\mathrm{ml}$ of acetonitrile. Volume was made up to mark with acetonitrile.

Working solution B (0.1\% choloranilic acid): From solution A pipette out $10 \mathrm{ml}$ and dilute to $100 \mathrm{ml}$ using acetonitrile. 


\section{Assay procedure}

$1 \mathrm{ml}$ of the intramuscular injection containing $250 \mathrm{mg}$ was transferred into $10 \mathrm{ml}$ volumetric flask. It was dissolved using distilled water. Finally, volume was made up to $10 \mathrm{ml}$ using distilled water. The solution was further diluted for analysis to get a concentration of $25 \mu \mathrm{g} / \mathrm{ml}$. The assay results are tabulated in table 2 .

\section{RESULTS AND DISCUSSION}

\section{Validation of the method $[13,14]$}

According to ICH guidelines validation of the method was carried out. Linearity, accuracy, precision, selectivity, robustness and ruggedness parameters were done.

\section{Linearity}

A series of amikacin sulfate solutions were prepared in the range of $20-100 \mu \mathrm{g} / \mathrm{ml}$ from the stock solution of $1000 \mu \mathrm{g} / \mathrm{ml}$. The resultant solution was measured at $524 \mathrm{~nm}$ against the reagent blank. The overlay graphs of absorption of the standard drug and calibration graph were shown in the fig. 2 and 3 respectively.

\section{Accuracy}

Accuracy is the nearness of the measured value to the obtained value of the sample.
To determine this three different standard concentrations of $50 \%$, $100 \%$ and $150 \%$ are added to the sample which is procured from the market. The results obtained for the spiked drug are given in \% recovery (94.44-106.4\%) shown in the table 3.

\section{Precision}

The precision of the analytical method was determined by measuring the fixed concentration of the drug solution for 6 times within the Beer's range and absorbance was found. The results of amikacin were given in the table 4-7.

\section{Limit of detection (LOD) and limit of quantitation (LOQ)}

The LOD and LOQ for amikacin sulfate were determined using calibration standards. The LOD and LOQ were calculated as $3.3^{*}$ standard deviation/slope and $10^{*}$ standard deviation/slope respectively.

\section{Robustness and ruggedness}

To determine the robustness of the method, reaction time and reagent concentrations were slightly altered with optimum values in spectrophotometry. To check the ruggedness, the analysis was done by four different analysts and on three different spectrophotometers using the same analyst. The robust data are expressed in \% RSD. The results of amikacin were in table 8 and 9.<smiles>CC(=O)NC1C[C@@H](N)[C@H](C[C@H]2O[C@H](CN)[C@@H](O)[C@H](O)[C@H]2O)[C@H](O)[C@H]1C[C@H]1O[C@H](CO)[C@@H](O)[C@H](N)[C@H]1O</smiles><smiles>O=C1C(O)=C(Cl)C(=O)C(O)=C1Cl</smiles>

\section{CHLORANILLIC ACID} AMIKACIN<smiles>CC(C)CCNC(=O)[C@H](O)CCN</smiles>

PURPLE COLORED COMPLEX

Fig. 2: Chemical reaction between amikacin and reagent

\section{Sandell's sensitivity}

The serial dilutions of $20-100 \mu \mathrm{g} / \mathrm{ml}$ solutions absorbance were taken and the sensitivity is calculated using the formula: Sandell's Sensitivity $(л)=$ Conc. $(\mu \mathrm{g} / 100 \mathrm{ml}) \times 0.001 / \mathrm{D} 1$ value. The results were given in the table 10 .

Selection of chloranillic acid reagent was based on the higher reactivity due to its stronger chromophore group in its structure when compared to other reagents. It enables its use for colourimetric determination of several amino groups.

The drug shows maximum absorption at $524 \mathrm{~nm}$ with a linearity range of $20-100 \mu \mathrm{g} / \mathrm{ml}$. The method is also validated for precision, accuracy, LOD, LOQ. The precision of the method was found to be $1.78 \mu \mathrm{g} / \mathrm{ml}, 1.76 \mu \mathrm{g} / \mathrm{ml}$ and $1.38 \mu \mathrm{g} / \mathrm{ml}$.

The percentage recovery was ranging from $94.44 \%$ to $106.94 \%$. And the LOD and LOQ were found to be $6.49 \mu \mathrm{g} / \mathrm{ml}$ and $19.68 \mu \mathrm{g} / \mathrm{ml}$ respectively. These data's confirms the method is very sensitive and effectively used for quantification of Amikacin sulfate.

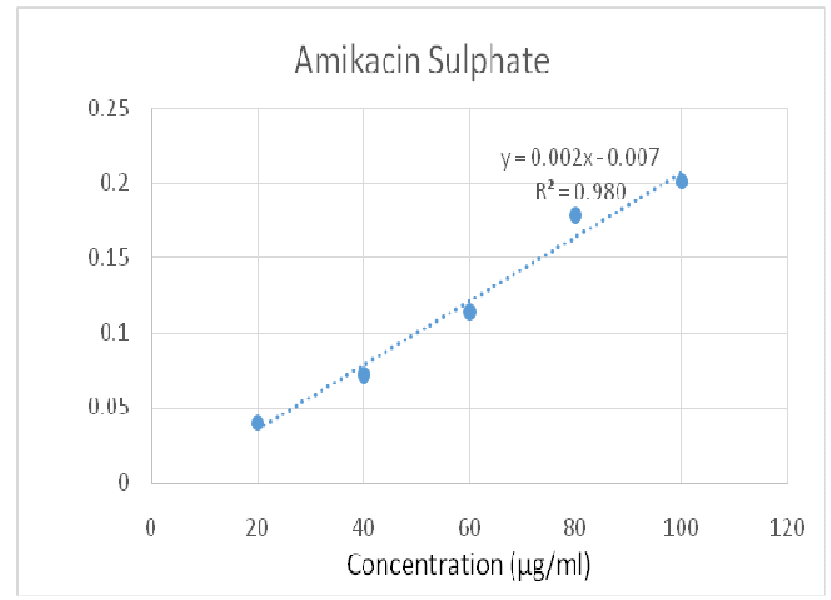

Fig. 3: Linearity plot for amikacin sulfate 


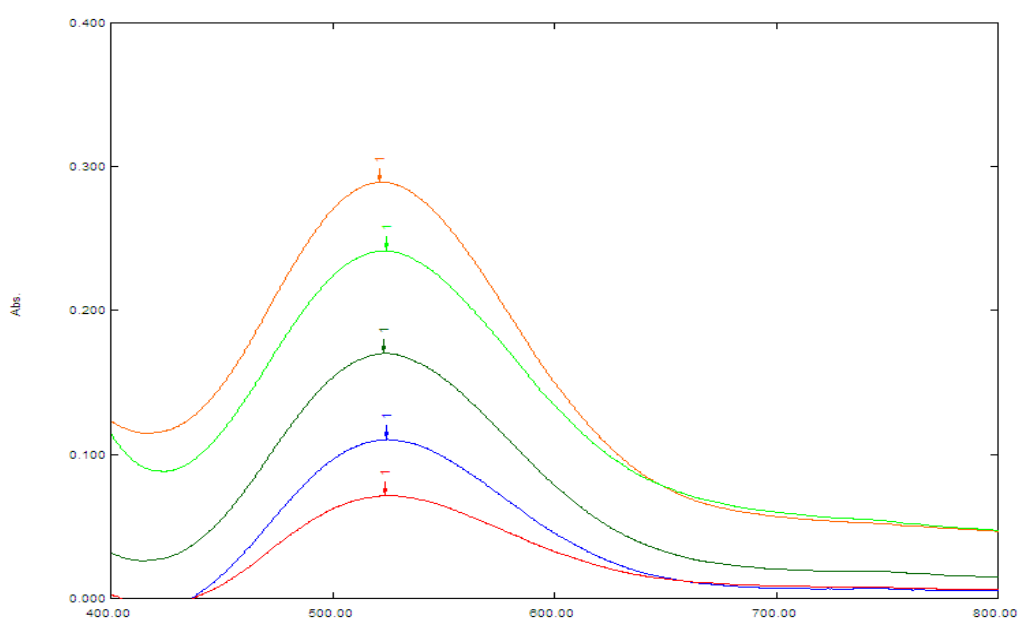

Fig. 4: Overlay absorption spectra of amikacin sulphate

Table 1: Optical parameters of the method

\begin{tabular}{ll}
\hline Parameters & Method \\
\hline גmax & $524 \mathrm{~nm}$ \\
Beers law limits $\mu \mathrm{g} / \mathrm{ml}$ & $20-100$ \\
Regression equation $\mathrm{y}=\mathrm{mx}+\mathrm{c}$ & $\mathrm{Y}=0.0021 \mathrm{x}-0.0075$ \\
Slope,m & 0.0021 \\
Intercept,c & -0.0075 \\
$\mathrm{LOD}, \mu \mathrm{g} / \mathrm{ml}$ & 6.49 \\
$\mathrm{LOQ}, \mu \mathrm{g} / \mathrm{ml}$ & 19.68 \\
Correlation coefficient $\left(\mathrm{r}^{2}\right)$ & 0.9803 \\
Sandell's Sensitivity, $\mu \mathrm{g} / \mathrm{cm}^{2} / 0.001 \mathrm{~A} . \mathrm{U}$. & 0.23 \\
Molar absorpitivity, $\mathrm{cm}^{-1} \mathrm{M}^{-1}$ & $0.122^{*} 10^{4}$ \\
\hline
\end{tabular}

Table 2: Assay procedures

\begin{tabular}{llll}
\hline Brand name & Available form & Label claim & Amount found \\
\hline MIKACIN & IM injection & $250 \mathrm{mg} / \mathrm{ml}$ & $248.97 \mathrm{mg} / \mathrm{ml}$ \\
\hline
\end{tabular}

Table: 3 Accuracy/\% recovery

\begin{tabular}{|c|c|c|c|c|c|c|c|}
\hline $\begin{array}{l}\text { Level of } \\
\text { recovery }\end{array}$ & $\begin{array}{l}\text { Amount of } \\
\text { formulation }(\mu \mathrm{g} / \mathrm{ml})\end{array}$ & $\begin{array}{l}\text { Amount of pure } \\
\text { drug }(\mu \mathrm{g} / \mathrm{ml})\end{array}$ & $\begin{array}{l}\text { Total amount of } \\
\text { drug }(\mu \mathrm{g} / \mathrm{ml})\end{array}$ & Absorbance & Difference & \% recovery & Mean \\
\hline \multirow{3}{*}{50} & 40 & 20 & 60 & 0.113 & 0.073 & 101.39 & 100.46 \\
\hline & 40 & 20 & 60 & 0.111 & 0.071 & 98.61 & \\
\hline & 40 & 20 & 60 & 0.113 & 0.073 & 101.39 & \\
\hline \multirow{3}{*}{100} & 40 & 40 & 80 & 0.143 & 0.071 & 98.61 & 100.92 \\
\hline & 40 & 40 & 80 & 0.149 & 0.077 & 106.94 & \\
\hline & 40 & 40 & 80 & 0.142 & 0.07 & 97.22 & \\
\hline \multirow{3}{*}{150} & 40 & 60 & 100 & 0.189 & 0.075 & 104.17 & 99.07 \\
\hline & 40 & 60 & 100 & 0.182 & 0.068 & 94.44 & \\
\hline & 40 & 60 & 100 & 0.185 & 0.071 & 98.61 & \\
\hline
\end{tabular}

Table 4: Method precision (intraday)

\begin{tabular}{lllll}
\hline Concentration $\boldsymbol{\mu g} / \mathbf{m l}$ & Absorbance & Concentration $\boldsymbol{\mu g} / \mathbf{m l}$ & Absorbance & Concentration $\boldsymbol{\mu g} / \mathbf{m l}$ \\
\hline & 0.0401 & & 0.11 & \\
20 & 0.0409 & 60 & 0.109 & 100 \\
& 0.042 & & 0.112 & 0.203 \\
& 0.0405 & & 0.11 & 0.21 \\
& 0.0409 & & 0.106 & 0.209 \\
Avg & 0.04 & Avg & 0.109 & 0.201 \\
SD & 0.0407 & SD & 0.002 & 0.203 \\
\%SD & 0.0006 & \%RSD & 1.83 & SD \\
\hline
\end{tabular}

Avg: Average SD: Standard Deviation RSD: Relative Standard Deviation 
Table 5: Method precision (interday)

\begin{tabular}{|c|c|c|c|c|c|}
\hline Concentration $\mu \mathrm{g} / \mathrm{ml}$ & Absorbance & Concentration $\mu \mathrm{g} / \mathrm{ml}$ & Absorbance & Concentration $\mu \mathrm{g} / \mathrm{ml}$ & Absorbance \\
\hline & 0.041 & & 0.109 & & 0.209 \\
\hline \multirow[t]{5}{*}{20} & 0.04 & 60 & 0.11 & 100 & 0.21 \\
\hline & 0.042 & & 0.113 & & 0.205 \\
\hline & 0.04 & & 0.112 & & 0.203 \\
\hline & 0.041 & & 0.11 & & 0.207 \\
\hline & 0.04 & & 0.115 & & 0.213 \\
\hline Avg & 0.0406 & Avg & 0.115 & Avg & 0.2078 \\
\hline SD & 0.0007 & SD & 0.002 & SD & 0.003 \\
\hline$\%$ RSD & 1.83 & $\%$ RSD & 1.84 & $\%$ RSD & 1.58 \\
\hline
\end{tabular}

Avg: Average SD: Standard Deviation RSD: Relative Standard Deviation

Table 6: System precision (intraday)

\begin{tabular}{|c|c|c|c|c|c|}
\hline Concentration $\mu \mathrm{g} / \mathrm{ml}$ & Absorbance & Concentration $\mu \mathrm{g} / \mathrm{ml}$ & Absorbance & Concentration $\mu \mathrm{g} / \mathrm{ml}$ & Absorbance \\
\hline \multirow[t]{6}{*}{20} & 0.04 & 60 & 0.109 & 100 & 0.199 \\
\hline & 0.04 & & 0.11 & & 0.203 \\
\hline & 0.042 & & 0.114 & & 0.201 \\
\hline & 0.04 & & 0.112 & & 0.2 \\
\hline & 0.04 & & 0.109 & & 0.197 \\
\hline & 0.0401 & & 0.113 & & 0.203 \\
\hline Avg & 0.0405 & Avg & 0.111 & Avg & 0.2005 \\
\hline SD & 0.0007 & $\mathrm{SD}$ & 0.001 & SD & 0.002 \\
\hline$\%$ RSD & 1.86 & $\%$ RSD & 1.75 & $\%$ RSD & 1.06 \\
\hline
\end{tabular}

Avg: Average SD: Standard Deviation RSD: Relative Standard Deviation

Table 7: System precision (interday)

\begin{tabular}{|c|c|c|c|c|c|}
\hline Concentration $\mu \mathrm{g} / \mathrm{ml}$ & Absorbance & Concentration $\mu \mathrm{g} / \mathrm{ml}$ & Absorbance & Concentration $\mu \mathrm{g} / \mathrm{ml}$ & Absorbance \\
\hline & 0.0401 & & 0.112 & & 0.201 \\
\hline \multirow[t]{5}{*}{20} & 0.04 & 60 & 0.114 & 100 & 0.199 \\
\hline & 0.0403 & & 0.109 & & 0.203 \\
\hline & 0.042 & & 0.11 & & 0.2 \\
\hline & 0.0399 & & 0.109 & & 0.201 \\
\hline & 0.0401 & & 0.11 & & 0.206 \\
\hline Avg & 0.0405 & Avg & 0.11 & Avg & 0.201 \\
\hline SD & 0.0007 & SD & 0.001 & SD & 0.002 \\
\hline$\%$ RSD & 1.82 & $\%$ RSD & 1.62 & $\%$ RSD & 1.13 \\
\hline
\end{tabular}

Avg: Average SD: Standard Deviation RSD: Relative Standard Deviation

Table 8: Robustness data of the developed method

\begin{tabular}{|c|c|c|c|c|c|}
\hline Wavelength (nm) & Concentration $\mu \mathrm{g} / \mathrm{ml}$ & Absorbance & Wavelength (nm) & Concentration $\mu \mathrm{g} / \mathrm{ml}$ & Absorbance \\
\hline \multirow[t]{6}{*}{523} & 60 & 0.114 & 525 & 60 & 0.114 \\
\hline & 60 & 0.112 & & 60 & 0.111 \\
\hline & 60 & 0.113 & & 60 & 0.113 \\
\hline & Avg & 0.113 & & Avg & 0.112 \\
\hline & St Dev & 0.001 & & St Dev & 0.001 \\
\hline & $\%$ RSD & 0.88 & & $\%$ RSD & 1.35 \\
\hline
\end{tabular}

Table 9: Ruggedness of the developed method

\begin{tabular}{|c|c|c|c|c|c|}
\hline Concentration $\mu \mathrm{g} / \mathrm{ml}$ & Linearity absorbance & Change in instrument absorbance & Mean & SD & \%RSD \\
\hline 0 & 0 & 0 & 0 & 0 & 0 \\
\hline 20 & 0.04 & 0.041 & 0.04 & 0.0007 & 1.74 \\
\hline 40 & 0.072 & 0.074 & 0.073 & 0.001 & 1.94 \\
\hline 60 & 0.114 & 0.112 & 0.113 & 0.001 & 1.25 \\
\hline 80 & 0.179 & 0.176 & 0.177 & 0.002 & 1.98 \\
\hline 100 & 0.201 & 0.205 & 0.203 & 0.003 & 1.39 \\
\hline
\end{tabular}

SD: Standard Deviation RSD: Relative Standard Deviation 
Table 10: Sandell's sensitivity

\begin{tabular}{llll}
\hline S. No. & Concentration $(\boldsymbol{\mu g} / \mathbf{m l})$ & Absorbance & Sensitivity \\
\hline 1 & 20 & 0.04 & 0.5 \\
2 & 40 & 0.072 & 0.278 \\
3 & 60 & 0.114 & 0.175 \\
4 & 80 & 0.179 & 0.112 \\
5 & 100 & 0.201 & 0.010 \\
\hline
\end{tabular}

\section{CONCLUSION}

The developed spectrophotometric method was easy, responsive and authentic with good precision and accuracy. The procedure did not involve any critical steps; hence it can be used routinely for determination of amikacin in pure and in the marketed formulation.

\section{AUTHORS CONTRIBUTIONS}

All the author have contributed equally

\section{CONFLICT OF INTERESTS}

Declared none

\section{REFERENCES}

1. Feng CH, Lin SJ, Wu HL, Chen SH. Trace analysis of amikacin in commercial preparation by derivatization and HPLC. J Liq Chroma Related Tech 2001;24:381-92.

2. Ovalles JF, Brunetto Mdel R, Gallignani M. A new method for the analysis of amikacin using 6-aminoquinolyl-N-hydroxysuccinimidyl carbamate (AQC) derivatization and highperformance liquid chromatography with UV-detection. J Pharm Biomed Anal 2005;39:294-8.

3. Galanakis EG, Megoulas NC, Solich P, Koupparis MA. Development and validation of a novel LC non-derivatization method for the determination of amikacin in pharmaceuticals based on evaporative light scattering detection. J Pharm Biomed Anal 2006;40:1114-20.

4. Ryan JA. Colorimetric determination of gentamicin, kanamycin, tobramycin, and amikacin aminoglycosides with 2,4dinitrofluorobenzene. J Pharm Sci 1984;73:1301-2.

5. Zawilla NH, Li B, Hoogmartens J, Adams E. Improved reversedphase liquid chromatographic method combined with pulsed electrochemical detection for the analysis of amikacin. J Pharm Biomed Anal 2007;43:168-73.

6. Maitra SK, Yoshikawa TT, Steyn CM, Guze LB, Schotz MC. Amikacin assay in serum by high-performance liquid chromatography. Antimicrob Agents Chemother 1978;14:880-5.

7. Sánchez Martinez ML, Aguilar Caballos MP, Gomez Hens A. Selective kinetic determination of amikacin in serum using long-wavelength fluorimetry. J Pharm Biomed Anal 2004;34:1021-7.

8. Dave Vimal M. Development and validation of an RP-HPLC method for simultaneous estimation of cefepime hydrochloride and amikacin sulphate in injection dosage form. J Pharm Sci Biosci Res 2012;2:58-62.

9. Nicoli S, Santi P. Assay of amikacin in the skin by highperformance liquid chromatography. J Pharm Biomed Anal 2006;41:994-7.

10. Baietto L, D'Avolio A, De Rosa FG, Garazzino S, Michelazzo M, Ventimiglia G, et al. Development and validation of a simultaneous extraction procedure for HPLC-MS quantification of daptomycin, amikacin, gentamicin, and rifampicin in human plasma. Anal Bioanal Chem 2010;396:791-8.

11. Fathima A, Rao S, Venkateshwarlu G. Quantitative determination of drugs and pharmaceuticals using pchloranilic acid as a reagent. Int J Chem Tech Res 2012;4:79-91.

12. Darwish IA, Refaat IH. Spectrophotometric analysis of selective serotonin reuptake inhibitors based on the formation of charge-transfer complexes with tetracyanoquinodimethane and chloranilic acid. J AOAC Int 2006;89:326-33.

13. ICH, Q2B, Validation of Analytical Procedures: Methodology, International Conference on Harmonization, Geneva; 1996. p. 1.

14. ICH, Q2(R1), Validation of analytical procedures: Text and Methodology; 1995. 